\title{
Employee Perceptions Of The Environmental Risk: Maquila Industries On The Mexico-U.S. Border
}

\author{
Rolando Pena-Sanchez, Texas A\&M International University, USA
}

\begin{abstract}
The Mexican maquila (assembly-for-export) industry has been involved in four main environmental risk areas of concern that affect residents of the border; these risks are: waterpollution, waste-management, air-pollution and water-availability. Our study shows a descriptive evaluation for the employees and/or supervisors perceptions of the environmental risk represented by their maquila industries located in the Mexican-U.S. border city of Nuevo-Laredo; where, its expected labor-force for year 2008 (an estimate of 24,480 employees) has been experiencing some reductions mainly due to the high cost of energy supplies and because some maquilas have emigrated to China. Furthermore, an estimate of $61.0 \%$ of these maquila's employees perceive an appropriate level of application of environmental laws. Although the majority of the maquila industry $(80.5 \%)$ at this border city possesses production-quality certifications, merely an estimate of $17.1 \%$ of such industrial-units (maquilas) have an international environmental-quality certification (ISO14000). The majority of the interviewed labor personnel agreed that an ISO14000 system in combination with any environmental risk reduction plan is the most effective strategy to prevent and minimize pollution.
\end{abstract}

Keywords: Maquila Industry, Mexico-U.S. Border, Environmental Risk, Descriptive Statistics

\section{INTRODUCTION}

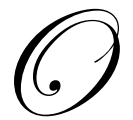

ne of the assumed reasons for maquilas also called maquiladoras (assembly-for-export companies) being located in Nuevo Laredo, as well in any other Mexican city, is because labor and other expenses are cheaper; this kind of discussions usually begins with a shared hypothesis that "low wages" are the major reason for this industry to be situated in Mexico. Another assumed reason is related to the flexibility of Mexican authorities with respect to the environmental laws application. For example, the U.S. has very rigid environmental and labor laws. Consequently, some maquilas find it very expensive to comply with such regulations, and move somewhere else to not have to comply with such laws. Thus, a combination of employees' low wages, and a soft application of environmental law could be result in increments of the profit margins for some manufacturing companies.

A maquila, is a business company which operates under a maquila program approved for by the Mexican Secretariat of Commerce and Industrial Development (SECOFI). "A maquila program entitles the company, first, to foreign investment participation in the capital -- and in management -- of up to $100 \%$ without need of any special authorization; second, it entitles the company to special customs treatment, allowing duty free temporary import of machinery, equipment, parts, materials, administrative equipment such as computers, and communications devices, subject only to posting a bond guaranteeing that such goods will not remain in Mexico permanently". (Source: http://www.udel.edu/leipzig/texts2/vox128.htm). 
Normally, all of a maquila's products are exported, either directly, or indirectly. They are sold through to another maquila or a custom broker. The type of production may be the simple assembly of temporarily imported goods; the manufacture from start to finish of a product using materials from several countries; or any mixture of the various phases involved in manufacturing, or even non-industrial operations, such as data-processing, wrapping and/or packaging products [[5] Gonzalez-Baz 1997].

The cooperative effort [[1] Cooke 1996] flanked by Mexico and the U. S. is known by different names; the most common are: "Border Industrialization Program", "Maquiladora Program" and/or "Maquila Program". A Mexican maquila operates under a special customs regime that allows the corporation to import into Mexico dutyfree, raw materials, equipment, machinery, replacement parts, and other items needed for the assembly or manufacture of finished goods for subsequent export. The term "In-bond Industry", is referring to the fact that goods are shipped from the U.S. to Mexico and back. The name "twin plants" depicts an association between an assembly facility on the Mexican side and a smaller processing and distribution plant on the American side [[5] Gonzalez-Baz 1997].

The legislation governing the maquila industry's operations, shows up in the "Decree for Development and Operation of the Maquila Industry", published on December 22, 1989 by the Mexican federal Diario Oficial. This Decree describes application procedures and requirements for obtaining a maquila program approval, and the special provisions that apply only to a maquila.

Source: http://www.udel.edu/leipzig/texts2/vox128.htm.

Nuevo Laredo is a Mexican border city located in the state of Tamaulipas. The population was estimated to be around 400,000 inhabitants in the year 2005, (http://www.inegi.gob.mx/) and has been experimented an exponential growth [[8] [Noggle 1993]. Figure 1 shows the population projections for both border-sister-cities: Nuevo-Laredo, Tamaulipas \& Laredo, Texas, where we can see the classic demographic-gap [[11] Pena-Sanchez 2005] of these adjacent cities separated by the Grande River.

Figure 1

Population projections for the international border cities of Nuevo Laredo, Tamaulipas and Laredo, Texas

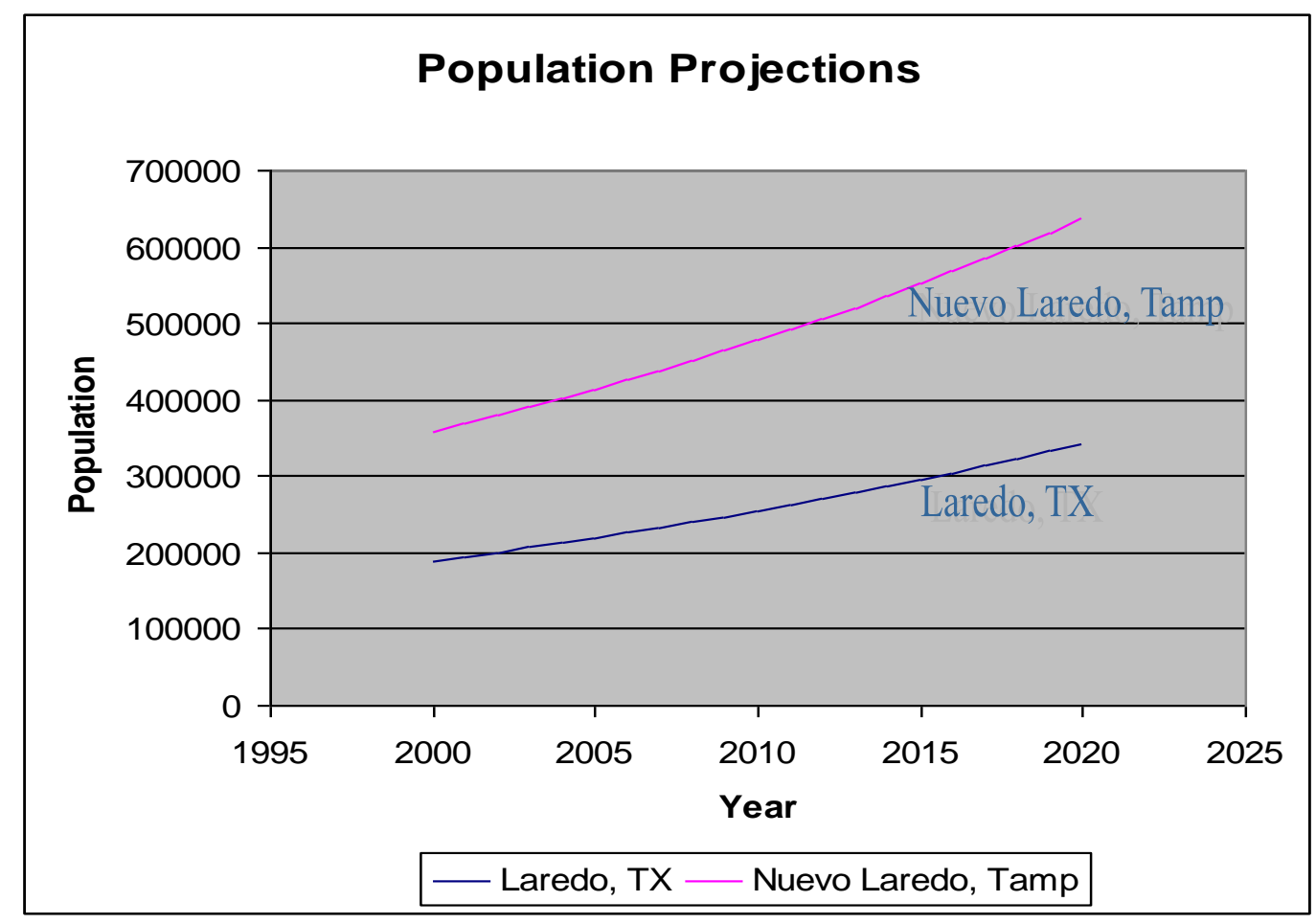




\section{OBJECTIVE}

To obtain descriptive estimates about the employees/supervisors perceptions on the environmental risk represented by the maquila industry for which they work, located in the Mexico-U.S. border at Nuevo-Laredo [[10] Pena-Sanchez 1997].

\section{DATA AND METHODOLOGY}

This study was carried out with a random sample of 41 employees' interviews from the maquila industry situated in the Mexico-U.S. border city of Nuevo Laredo in the state of Tamaulipas. An invitation to participate in a personal meeting (of 15 minutes in average) was extended to all maquila companies, but only some of the employees/supervisors accepted to answer our questions oriented to estimate [[7] Leedy 2001] their perceptions on the environmental risk represented by the industries for which they work. The sample obtained on the two previous years of 2007 and during such year, was representing $74.5 \%$ of the entire maquila industry $(\mathrm{N}=55)$ at Nuevo Laredo, Tamp.-Mexico; where, 33 (or 81\%) of the 41 interviewed employees/supervisors requested to remain anonymous. The maquilas that did not participate, they rejected the invitation again during 2006 and/or 2007 by having costlabor problems, cost-production's problems, or by do not to have passed the corresponding certifications and/or because they had been planning to relocate their maquila-industries in another country like China. The number of employees per maquila was updated on March-2008 [[12] Richards 2008].

\section{DESCRIPTIVE STATISTICS AND DISCUSSIONS}

From Table 1 we can observe that the majority $(80.5 \%)$ of the Maquila Industry has production quality (ISO9000) certification, but only $17.1 \%$ has an ISO14000 (environmental quality) certification.

Table 1

Has your Company been certified?

\begin{tabular}{|l|c|c|c|}
\hline \multicolumn{1}{|c|}{ Answer } & Frequency & Percent & Cumulative Percent \\
\hline No certification & 8 & 19.5 & 19.5 \\
ISO9000 & 11 & 26.8 & 46.3 \\
ISO9000 and ISO14000 & 7 & 17.1 & 63.4 \\
ISO9000 and other & 8 & 19.5 & 82.9 \\
Other certification & 7 & 17.1 & 100.0 \\
Total & 41 & 100.0 & \\
\hline
\end{tabular}

With respect to the answer "No" in Table 2A, there are 3 types of "No": The first type was a excusable No (34.1\%), because the interviewed employees had no information if a fine occurred (lack of information), this category is equivalent to reply: "I don't know"; the $2^{\text {nd }}$ type of "No" was a convincible No, $(24.4 \%)$, where the employees knew that no-fines were assigned to his/her maquila company; and the $3^{\text {rd }}$ type of "No" was a conditional No $(22 \%)$, when the employees were advised to not release this kind of information.

Table 2A

Has your Company received a fine from an environmental authority?

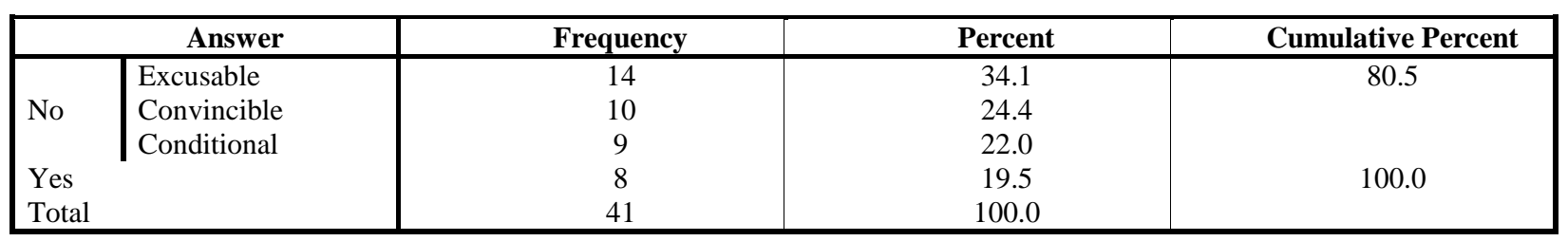


Table 2B specifies "why" the fine was assigned, as well as its corresponding year. Only $19.5 \%$ of the interviewed employees were willing to collaborate with this critical information. Where, most of the fine's cases are related to a wrong or bad waste-management.

Table 2B

If your Company received a fine; When and Why?

\begin{tabular}{|c|l|}
\hline $\begin{array}{c}\text { When the fine occurred } \\
\text { (What year?) }\end{array}$ & \multicolumn{1}{c|}{ Why the fine occurred? } \\
\hline 1996 & $\begin{array}{l}\text { Because the storage-room for dangerous waste had not written its legend at its entrance } \\
\text { We had initiated a process and we had not manifested before to the environmental authd } \\
\text { (PROFEPA) one dangerous waste } \\
\text { Due to the bad disposal of filters and industrial water. Shortage of water was reported } \\
\text { By not giving a declaration of textiles-waste mixed with oil } \\
\text { Due to the lack of identification of some dangerous wastes } \\
\text { By burning trash, which had been producing air pollution } \\
\text { By not giving a declaration of a dangerous waste } \\
\text { Wrong disposal and bad management of oils and dangerous wastes, which has been producin } \\
\text { contamination into soil and underground water }\end{array}$ \\
2000 &
\end{tabular}

The excusable answer "No" in Table 3, represents the percentage (29.3\%) of employees or supervisors whose reply was "I don't know"; the convincible answer "No" $(14.7 \%)$ is the percentage of employees that already knew that his/her maquila had no external legal office for environmental issues; meanwhile a conditional "No" is the percentage $(4.8 \%)$ of employees that were advised to not release this kind of information. Table 4 shows very similar results, where the proportion of employees that have seen an increase in the environmental number of laws since NAFTA implementation was around 56.1\%; parallel to this evaluation, and according to Table 5, an estimate of $61.0 \%$ of maquila's employees perceives an appropriate level of application of environmental laws.

Table 3

Does your company have an external department (legal office, or technical advisers) that handles its environmental issues?

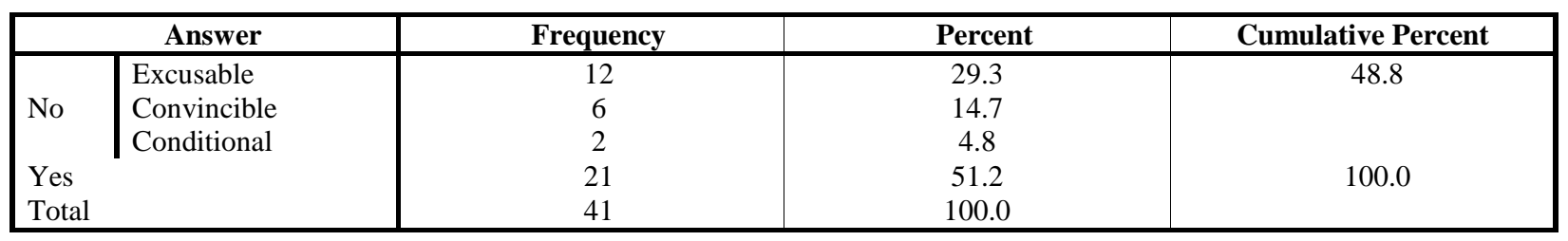

Table 4

Have you seen an increase in the environmental number of laws locally (by PROFEPA), since NAFTA implementation?

\begin{tabular}{|l|c|c|c|c|}
\hline \multicolumn{2}{|c|}{ Answer } & Frequency & Percent & Cumulative Percent \\
\hline \multirow{3}{*}{ No } & Excusable & 11 & 26.8 & 43.9 \\
& Convincible & 5 & 12.2 & \\
Yes & Conditional & 2 & 4.8 & 100.0 \\
Total & & 23 & 56.1 & 100.0 \\
\hline
\end{tabular}


Table 5

Have you seen an appropriate level of application of environmental laws since NAFTA implementation?

\begin{tabular}{|l|c|c|c|c|}
\hline \multicolumn{2}{|c|}{ Answer } & Frequency & Percent & Cumulative Percent \\
\hline \multirow{3}{*}{ No } & Excusable & 11 & 26.8 & 39.0 \\
& Convincible & 3 & 7.4 & 100.0 \\
Yes & Conditional & 2 & 4.8 & \\
Total & & 25 & 100.0 & \\
\hline
\end{tabular}

On Table 6, we can observe that the majority (65.9\%) of the maquilas return their wastes to the origin's country. Most of these wastes, (metal residuals) have an economical value. The category "Does not apply" belongs to those maquilas that do not generate wastes (for example, those companies dedicated to the packing of goods), which also applies for Table 7, where some of the employees/supervisors $(31.7 \%)$ had not idea about the existence of technical supporting programs for handling dangerous wastes. The North American Development Bank, (NAD Bank), is an American institution dedicated to support corporations in its development of environmental infrastructure. U.S.-Mexico Environmental Program, (Border 2012), is an agenda of collaboration between the United States and Mexico to improve the environment, prevent pollution, [[4] EPA 1996] and protect the health of the almost 12 million people living next to the border. P4 is the Permanent Pollution Prevention Program developed by the Border Environment Cooperation Commission (BECC) in coordination with the Environmental Protection Agency (EPA).

\section{Table 6}

Does your company return or send its waste to the origin's country, since the NAFTA agreement expresses that all products, including chemicals' processing introduced under the agreement should be returned?

\begin{tabular}{|l|c|c|c|c|}
\hline \multicolumn{2}{|c|}{ Answer } & Frequency & Percent & Cumulative Percent \\
\hline \multirow{3}{*}{ No } & Excusable & 3 & 19.5 & 19.5 \\
\cline { 2 - 4 } & Convincible & 3 & & 85.4 \\
\cline { 2 - 5 } Yes & Conditional & 2 & 65.9 & 100.0 \\
Does not apply & 27 & 14.6 & \\
\multicolumn{2}{l|}{ Total } & 6 & 100.0 & \\
\hline
\end{tabular}

Table 7

Is your company aware of programs (NAD Bank, Border 2012, P4, etc.) that offer technical aid in handling hazardous wastes?

\begin{tabular}{|l|l|l|l|}
\hline Answer & Frequency & Percent & Cumulative Percent \\
\hline No (Excusable) & 13 & 31.7 & 31.7 \\
Yes & 22 & 53.7 & 85.4 \\
Does not apply & 6 & 14.6 & 100.0 \\
Total & 41 & 100.0 & \\
\hline
\end{tabular}

The maquila industries are being affected by the resources of energy's high-costs and have had to reduce its number of employees [[12] Richards 2008]. A labor-force estimate with a 95\% confidence for the year 2008 at Nuevo Laredo is approximately 24,480 \pm 9,175 employees, which appears in Table 8. 
Table 8

Number of employees' statistics

\begin{tabular}{|c|c|l|c|c|}
\hline Minimum & Maximum & Mean & $\begin{array}{c}\text { Standard } \\
\text { Deviation }\end{array}$ & $\begin{array}{c}\text { A 95\% Confidence Interval for the total number of employees } \\
\text { at Nuevo Laredo's Maquilas for 2008 }\end{array}$ \\
\hline 25 & 2958 & 445.12 & 544.93 & $24480 \pm 9175$ \\
\hline
\end{tabular}

Figure 2 contains combined statistics [[3] Cooper 2008] from Tables 1 and 8 in order to see how these companies with a large number of employees got their respective ISO9000 and ISO14000 certifications.

Figure 2

Number of employees per certification status

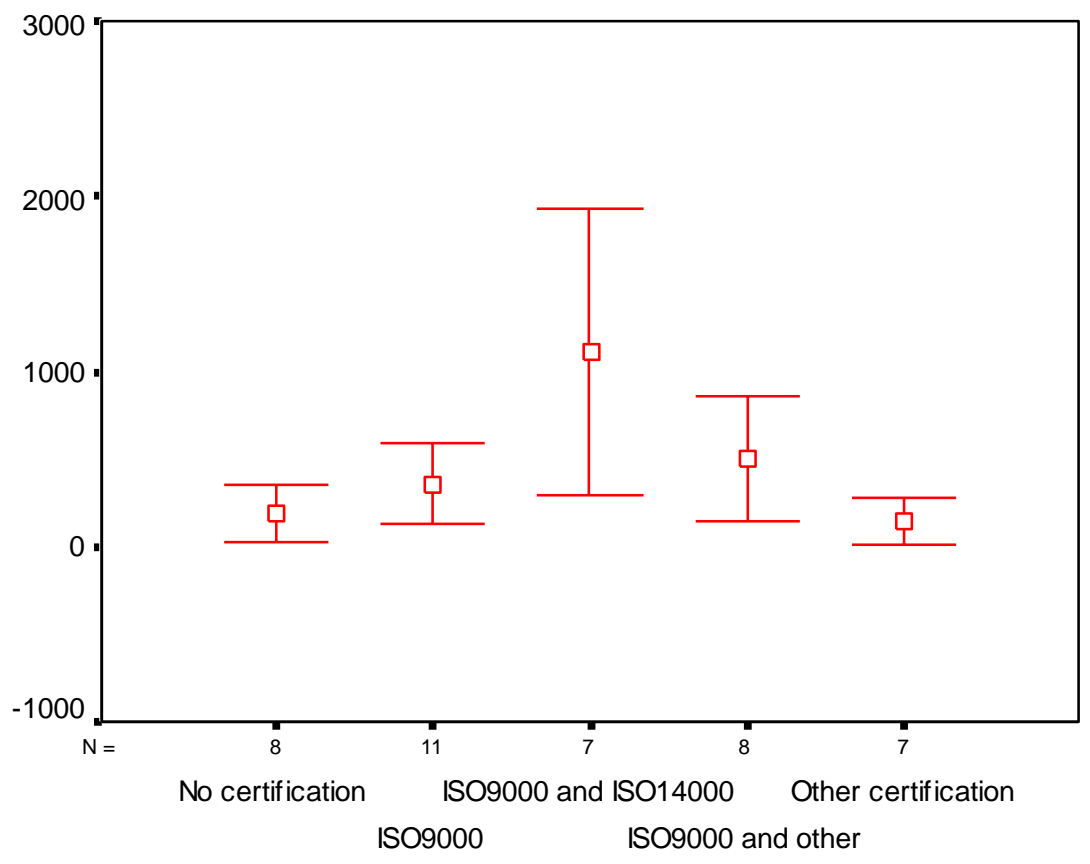

STATUS

\section{CONCLUSIONS}

From Tables 2A and 2B, we can conclude that the Mexican maquila industry has been involved in four main environmental risk areas that affect residents of the border: water-pollution, waste-management, air-pollution and water-availability. Although the majority of the maquila industry $(80.5 \%)$ in this border city possesses production-quality certifications (Table 1), merely an estimate of $17.1 \%$ of such industrial-units have an international environmental-quality ISO14000 certification, and an estimate of $19.5 \%$ of these industrial units remain without any type of certification. Thus, an additional effort from the Mexican environmental authorities will be necessary to convince these maquilas about the benefits of clean-industry programs.

In Nuevo Laredo, the application of the environmental law is not completely reliable; $39.0 \%$ of maquila's employees do not trust the application of the environmental law; this employee proportion has shown their doubts in the application of the environmental regulation. Only $61.0 \%$ of employees perceive an appropriate level of application of environmental laws; these estimates show up in Table 5. In addition, the maquila's labor force is in a negative gradient: The maquila industry is being affected by the high costs of electricity, hydrocarbons (natural gas, gasoline, diesel, etc.) and water [[11] Pena-Sanchez 2005]. As consequence of these high costs, they have had to reduce their labor personnel, which in combination with the fact that some bonded assembly plants have emigrated 
to China; this has caused the number of employees to diminish. Our $95 \%$ confidence Interval for the total number of employees at Nuevo Laredo's Maquilas: 24,480 $\pm 9,175$ jobs (Table 8) is an estimate of the labor force for the year 2008.

The answer "Yes" in Table 3 until Table 7 exceeds 50\%; then, for the majority of the interviewed maquila industry personnel (supervisors and employees), is clear that an ISO14000 Environmental Management System in combination with any risk reduction management and/or policy is the most effective strategy to prevent and minimize pollution; but, for the maquila's owners, directors and/or managers: If sustainability means "meeting the needs of the present without compromising the ability of future generations to meet their own needs". (Source: http://www.epa.gov/sustainability/) what percentage of their money are willing to invest in order to protect and to preserve our environment for the present and future generations?

The main argument of maquila industry's promoters is that any change in the existing economy [[9] Peach 1999] or environmental law (economic and environmental fears) that lead to higher-cost anti-pollution systems, and higher wages for workers will effectively undermine the industry's competitiveness [[14] Yoskowitz 2002]; and result in a significant emigration of corporations and jobs, as parent organizations relocate operations to countries with flexible environmental laws and lower labor costs [[13] Santibanez-Romellon 2001].

Thus, we have arrived to another conclusion, the environmental Mexicans authorities are in a disjunctive; these authorities are in the position to require the fulfillment of the environmental laws, but the risk exists that some maquilas could emigrate to another country and then many jobs would be lost; and this is going to produce a more serious social problem than the environmental problem.

At world level, during the meeting in Toyako, Japan on July 8, 2008 [[6] Kubota 2008]:

(Reuters) - Big emerging economies will come under pressure on Wednesday to respond in kind to an initiative by rich countries to work towards a target of at least halving their global greenhouse gas emissions by 2050. The Group of Eight (G8) industrial nations want the leaders of eight fast-growing countries to adopt a "shared vision" of tackling global warming in U.N. negotiations due to conclude in Copenhagen in December 2009. There has been major progress on the climate change agenda beyond what people thought possible a few months ago, British Prime Minister Gordon Brown said of Tuesday's agreement. For the first time the G8 has said we will adopt at least a 50 percent reduction in carbon emissions by 2050 as part of a worldwide agreement that we hope to get in Copenhagen; he said

Source: http://ca.news.yahoo.com/s/reuters/080708/world/international_g8_dc_21

If the presidents, prime ministers and representatives of developed countries agreed to reduce $50 \%$ of their air contaminants until the year 2050; probably, will be too late for many polluted regions, where the costs of publichealth due to contamination are exceeding the costs of pollution-prevention.

The G8 nations are: the United States, Japan, Russia, Germany, France, Britain, Canada and Italy; while, the group G5 is conformed by: India, China, Brazil, South Africa and Mexico.

In summary, this study achieved its objectives in obtaining descriptive estimates (Table 1 to Table 7) [[1] Cooke, 1996] and the respective conclusions of employees/supervisors perceptions on the environmental risk from the maquiladora industry, located in the North-Mexican border at Nuevo-Laredo.

\section{REFERENCES}

1. Conover, W. J. 1999 'Practical Nonparametric Statistics', 3rd Ed. John Wiley \& Sons.

2. Cooke, Gregg A. "Analysis of the border environment cooperation commission and the North American development bank and their potential impact upon environmental infrastructure construction in the TexasMexico border region“. 9th Annual Construction Law Conference. Houston. February 8-9, 1996.

3. Cooper, D. R. \& Schindler, P. S. 2008 'Business Research Methods', 10th Ed. McGraw-Hill 
4. $\quad$ EPA (Environmental Protection Agency) \& Mexico-SEMARNAP. "Pollution Prevention In The Electronics“. A manual written by a work group on May 1996. Source: http://www.epa.gov/Region06/6en/xp/electron.pdf, Site: http://www.epa.gov/epaoswer/hazwaste/recycle/ecycling/pubs.htm

5. Gonzalez-Baz, A. "What is a maquiladora? ". Published by Banco Nacional de Comercio Exterior (National Society of Credit) on February 20, 1997. Source: http://www.udel.edu/leipzig/texts2/vox128.htm Alternative source: http://www.bancomext-mtl.com/invest/vox128.htm

6. Kubota, Y. and Shchedrov, O. 2008 "G8 set for showdown with poorer states over climate". Source: Reuters news agency at: http://ca.news.yahoo.com/s/reuters/080708/world/international_g8_dc_21

7. Leedy, P. D., and Ormrod, J. E. 2001 'Practical Research: Planning and Design'. Seventh Edition. Merrill Prentice Hall.

8. Noggle, Joseph H. 1993 'Practical Curve Fitting and Data Analysis: Software and self-instruction for Scientists and Engineers'. Prentice Hall.

9. Peach, J. and Williams, J. 1999 "Population and Economics on the US-Mexico Border: Past, Present and Future". New Mexico State University.

10. Pena-Sanchez, R. 1997 “A Social-Economic Profile of Nuevo Laredo Tamp. “. DIC. UAT-Library. Ciudad Victoria, Tamp. México. Vol. 1, pp. 1-243.

11. Pena-Sanchez, R. A. 2005 "Nonparametric Comparison of the Per Capita Yearly Economic Needs for the Water Supply in the USA-Mexico Border Region“. International Business and Economics Research Journal. Vol. 4, Number 6, pp 35-46.

12. Richards, Ashley. 2008 “Nuevo. Laredo's CODEIN expects growth". Laredo Development Foundation., Source: http://ldfonline.org/shownews.asp?newsid=93

13. Santibanez-Romellon J., and Cruz-Pineiro, R. 2001 "Mercados Laborales Fronterizos". El Colegio de la Frontera Norte. México. pp. 1-129,

14. Yoskowitz, D.W., Giermanski, J.R. and Pena-Sanchez, R. 2002 "The Influence of NAFTA on SocioEconomic Variables for the US -Mexico Border Region“. The Journal of the Regional Studies Association. Volume 36, Number 1, pp. 25-31. 